\title{
A Study on Factors Affecting Intention of Choosing Internet Banking and Intention of Continuity
}

\author{
Chang Ok, Jin ${ }^{1} \&$ Sang-Bum Park ${ }^{1}$ \\ ${ }^{1}$ Department of Business Administration, Korea Aerospace University, Korea \\ Correspondence: Sang-Bum Park, Professor, Department of Business Administration, Korea Space University, \\ Korea. E-mail: psb@kau.ac.kr
}

Received: October 23, 2018

Accepted: November 1, 2018

Online Published: November 10, 2018

doi:10.5539/ijef.v10n12p54

URL: https://doi.org/10.5539/ijef.v10n12p54

\begin{abstract}
Purpose - The finance industry especially the banking industry has been facing unprecedented atmosphere due to Internet Specialized Bank, P2P financing, mobile banking, etc. Furthermore borrowing and lending task which is the core business of banking can be done by internet without visiting bank. So called new business platform for the banking industry has emerging, and accordingly banks have to find new strategies to survive. Banks need to maintain existing customers by understanding customers' perceived value and attract new customers. In this research, we investigate the relationship among Internet Banking Use, Trust, Bank Loyalty, Continuity, and Switching Barrier. The variables represent what customers perceive as values regarding banking and what make them to switch banks. Especially switching barriers are analyzed whether they have control effects on customers' behavior leaving or staying their current bank. By understanding factors affecting customers' decision making, banks can set up strategies not to lose existing customers and to attract new customers.
\end{abstract}

Research design, data, and methodology - The first step is to test whether the customers' perceived value on internet banking affect internet banking use and bank loyalty. The second step is to test trust which consists of system trust and bank trust affect internet banking use affects internet banking use and bank loyalty. The third step is to analyze whether switching barriers for internet banking have control effect on leaving the current or staying. The data was collected by questionnaire and analyzed using SPSS. Demographic characteristics, factor analysis, regression analysis, and 3 step regression analysis were conducted.

Results - All sub-variables of customers' perceive value, usefulness, ease of use, customization, convenience, is turned out to affect internet banking use and bank loyalty at statistically significant level. Of system trust which consists of two sub-variables, task performance trust and security trust, task performance affects internet banking use and bank loyalty but security trust does not. Three sub-variables of Bank trust, promise keeping, opportunistic behavior, employee trust, affect internet banking use but regarding bank loyalty promise keeping and employee trust affect but opportunistic behavior does not affect bank loyalty. The switching barriers for internet banking are turned out to have control effect on the process from internet banking use to continuity and from bank loyalty to continuity.

Conclusions - The customers' perceived value on internet banking use are chosen from extant study results. They are usefulness, customization, ease of use and convenience. All the four variables are meaningful regarding internet banking. Regarding trust, customers are still suspicious on security of the system. However customers have confidence in internet banking in terms of tasks. Of bank trust customers believe that banks will keep their promises and the employees are trustworthy but they also think that banks can make decisions for their own benefit when conflicts between customers and bank break out. The switching barriers which consist of three factors, switching costs, difficulties of new environment and uncertainties of new bank, have control effect on switching internet banks. Therefor for banks not to lose existing customers need to make the barriers higher.

The contribution of this study is as follows. First, we found what factors regarding customers' perceived value on internet banking affect the use. Second the trust regarding internet banking has to be divided into two aspects which are system trust and trust of bank itself. Finally, the switching barriers on internet banking are influential to switching banks and continuity.

Keywords: perceived customer value, system trust, bank trust, bank loyalty, switching barrier 


\section{Introduction}

In our daily life, convenience, speed has been very important virtue in decision making. This attitude can also be applied to banking. Banks have introduced tele-banking, internet-banking, and mobile-banking to meet customers' need. These new banking channels are not only for customers' need but also for banks' strategic measure. For banks, the number of branch was one of the most important measure determining their competitiveness, income size because in a branch most banking related tasks were handled. However the atmosphere surrounding banking industry has been changed very rapidly and fundamentally. The competitiveness among banks has been sharp, and external conditions including financial crises have affected the banking industry. However, the most dramatic change has been technical innovation. Most banking tasks are no long done in a branch face-to-face, instead telephone, internet system or mobile networks have replaced the role of branch office or clerks. With these rapidly changing conditions mean new competing paradigm to bank. This competing ground is no long for among banks only, which means new intruders including authorizing pay and check task specializing business as well as new internet banks. Banks need to keep their existing customers and attract new customers created by new business route.

The center of competing paradigm is internet banking because the number of use or the amount of trade through internet banking is not comparable to the other banking channels and the lending task which is the basic source of income to banks has been done using internet. So, competitiveness of internet banking is the key for a bank to gain competitiveness in the banking industry. The ultimate goal of internet banking is cutting costs by reducing face-to-face tasks and increasing revenues. Reducing face-to-face tasks can give convenience to customers by reducing time and efforts. All the effects can be taken only when a bank secures certain number of customers.

Banks have to understand what make customers use internet to secure existing customers and attract new customers. In this research, factors affecting customers' internet banking use. As factors customers' perceived value, trust, bank loyalty are considered and also switching barriers are investigated to analyze switching intention.

\section{Theoretical Background and Precedent Studies}

From precedent studies, the factors affecting internet banking are customers' perceived value, trust toward bank and internet system, loyalty, and switching variable.

\subsection{Perceived Customer Value}

Customers' perceive value includes many meanings and accordingly researchers define the value differently. From consumer's point of view, the value is feeling of satisfaction or utility from consuming product or service and measured size of the feeling is perceived value (Berger \& Nasr, 1988; Gupta \& Lehmann, 2004). For providers, the contributing interests provided as customers consume goods and services can be defined as customers' perceived value (Jain \& Singh, 2002).

Reflecting the diversity of customer perceived value, Sweeney and Soutar (2001) suggest multi-facet components of the concept, emotional value, social value, and functional value as shown in the Table 1

Table 1. Multi-facet components of customer value

\begin{tabular}{ll}
\hline Customer Value & Contents \\
\hline Emotional value & feeling or emotional value derived from products or services \\
Social value & social value derived from products \\
Functional value & value from saving time or reducing costs \\
Quality & value derived from the difference between expected performance and perceived quality \\
\hline
\end{tabular}

Internet banking is treating financial information for the purpose of financial transactions. Internet banking can be viewed as one of electronic commerce distributing information and service based on systems of software and networks (Kim \& Kim, 2002). So the customers' perceived value also reflects the characteristics of the system. As for the customers' perceived value, researchers' suggestions are different. For example, Noh and Lee (2005) introduce ease of use, customization, site composition and design, reaction time, information quality, Kim and Kim (2002) show usefulness, trust, customization, ease of use, fun, while HAN (2004) argue usefulness of information, economic usefulness, customization.

Rafi and Alnaser (2017) report that e-customer service and perceived value significantly influence on internet banking adoption and brand loyalty of Banks for the case of Malaysia. Abdallah et al. (2018) argue that in Jordan 
behavioral intention is significantly influenced by performance expectancy, effort expectancy, hedonic motivation, price value and perceived risk; however, social influence does not have a significant impact on behavioral intention. According to Berraies et al. (2017), quality, price and emotional perceived values' dimensions of MB applications are predictors of customers' e-trust. Within this spectrum, age acts as a moderator in these latter relationships. Findings also suggested that e-trust has positive effects on e-satisfaction and e-loyalty. In this research, the main purpose is to investigate factors affecting customers' internet banking adoption and continuity. Reflecting the characteristics of internet banking, we choose the components of customers' perceived value as usefulness, ease of use, customization, and convenience.

\subsection{Trust}

Although concept of trust has been defined differently (Curral \& Judge, 1995; Mayers et al., 1995; Nooteboom et al., 1997, etc.), trust is credibility formed between persons involved. Regarding internet banking, trust performs its role in determining whether to use internet banking or not. To make contracts to use internet banking, lots of personal information is asked to provide to banks, customers are worried about information leakage by hackers or other groups for improper use.

Regarding internet banking trust, trust for internet system and trust for bank itself should be classified separately (Kim et al., 2003). Trust for the system means customers' belief and expectation that the system can perform as they intended. On the other hand, trust for the bank is that customers believe banks will keep their promise, banks do not misuse customers' information, and employees of the bank are trustworthy. Trust for the system as a channel of banking is customers' expectation and belief in the electronic commerce and consists of main will to adopt internet banking. In this research, trust for the system and trust for the bank is separately considered.

\subsection{Loyalty}

Customer loyalty is not only a favorable attitude toward certain goods or services but also referencing the attitudes to surrounding people (Gerpott, Rams, \& Schindler, 2001; Zeithaml, Berry, \& Parasuraman, 1996). Or customer loyalty is emotional condition preferring, addicting to or affectionate to certain firm's employees, goods and services and mind or immersion to buy or use again (Oliver, 1997). Definition of customer loyalty can be explained by three methods of approaches, that is, approach of action, approach of attitude, and approach of unification (Dick \& Basu, 1994; Oh, 1995).

The approach of unification is integrating approaches of action and attitude to define the definition synthetically (Dick \& Basu, 1994; Oliver, 1997; Zeithaml, 2000). In this research we follow the approach of unification approach and see the customer loyalty comprising both attitude and action.

\subsection{Switching Barrier}

Switching barrier means all the physical, human, emotional, situational factors blocking changing trading partner. Although switching barrier helps current goods and services providers to keep existing customers, for providers trying to attract new customers switching barrier acts as obstacles.

Recently of switching barriers switching costs have the spotlight (Jones et al., 2002; Keaveney, 1995). Generally speaking, switching costs include psychological, emotional cost as well as economic costs. Also switching costs contain costs to change to an alternative (Jones, 2002). Switching cost is customers' perceived monetary and non-monetary costs that have to be paid when changing existing provider (Gremler, 1995). As customers recognize switching costs as obstacle to changing trading partner, they show loyalty to existing partner continuously (Ganesan, 1994).

In this research, as switching barriers for internet banking, we adopt switching costs (Dick \& Basu, 1994), human factors (Berry \& Parasuraman, 1991), and attractiveness of alternatives (Anderson \& Narus, 1990)

\subsection{Continuity}

Continuity means customer's intention to continue current relationship with existing partner who is satisfied with existing provider's goods and services (Yun et al., 2013). Continuity intension is an attitude that a customer wants to continue the relationship with existing provider. For a firm customer's continuity intension is definite source of profit and new customers who can be influenced by the customer with continuity intension (Kalwani \& Narayandas, 1995). Customers develop trust and expectation and hold intension to keep the trade in the future (Shin, 2011). As result variables repurchase intension and repetitive purchase action (Dick \& Basu, 1994), intention to reference (Tuškej, Golob, \& Podnar, 2011), variation of switching costs (Gremler, 1995), brand loyalty (LaBarbera \& Mazursky, 1993) are suggested. 


\section{Design of Research}

\subsection{Operational Definition and Hypotheses}

The main focus of this research is on internet banking. And more specifically relation among variables of customer values, trust, bank loyalty, switching barriers, continuity intension that are supposed to affect internet banking is analyzed. Customer values from internet banking are benefits related parts. That is, those values are coming from benefits of interests, support, and convenience of doing tasks using internet banking. Due to these benefits, customers bear costs of time and efforts to learn, endure possible losses caused from mistakes doing internet banking (Noh \& Lee, 2005; Han, 2004; Kim et al., 2003).

In this research, based on above discussion we define customer value as benefits from using internet banking, and set up the following hypothesis.

H1. Customer values regarding internet banking affect internet banking use.

As sub-variable of customer value, usefulness, ease of use, customization, and convenience are chosen. Thus the following hypotheses are set up.

H1-1. Usefulness of customer values affects internet banking use

H1-2. Ease of use of customer values affects internet banking use

H1-3. Customization of customer values affects internet banking use

H1-4. Convenience of customer values affects internet banking use

Customer values related to internet banking give customers positive mind about bank itself and bank related tasks. Kim and Kim (2002) show that loyalty for internet banking site affects loyalty toward bank itself by empirical analysis. So, the following hypotheses are chosen.

H2. Customer values about internet banking affect bank loyalty.

H2-1. Usefulness of customer values affects bank loyalty.

H2-2. Ease of use of customer values affects bank loyalty.

H2-3. Customization of customer values affects bank loyalty.

H2-4. Convenience of customer values affects bank loyalty.

Internet banking is one of electronic commerce distributing information and service built on various software and network (Kim \& Kim, 2002). This kind of system is always followed by trust issue. Risks of system malfunction, hacking, misuse of customers' personal information exist. These kinds of risks also affect customer choosing internet banking. Customers use internet banking because of system trust and bank trust in spite of these risks. So we set up the following hypotheses. And of trust toward system, there are two sub-variables, task performance trust and security trust.

H3. System trust affects internet banking use.

H3-1. Task performance trust of system trust affects internet banking use.

H3-2. Security trust of system trust affects internet banking use.

In this research, trust is divided into trust for network system for internet banking and trust for bank itself (Nooteboom et al., 1997; Kim et al., 2003). Trust for bank consists of three sub-variables, to keep promises, not to act opportunistically, and employee trust. According to these discuss, the following hypotheses are set up.

H4. Bank trust affects bank loyalty.

H4-1. Keeping promises of bank trust affects bank loyalty.

H4-2. Opportunistic action of bank trust affects bank loyalty.

H4-3. Employee trust of bank trust affects bank loyalty.

bbBank trust, bank loyalty affects internet banking use (Kim et al., 2003). Bank loyalty based on trust indicates system trust and loyalty (Lee, 2015), thus affects internet banking use. So we establish the following hypothesis.

H5. Bank loyalty affects internet banking use.

When choosing internet banking, it has been shown that customer loyalty for internet banking site affects bank loyalty affirmatively (Kim \& Kim, 2002; Lee, 2015). The emerging of internet specialized banking indicates that the lending and borrowing money process which is bank core task will be dome through internet. Therefore 
customers tend to thing internet banking bank as main bank. Based on these discusses, we set up the following hypothesis.

H6. Internet banking affects bank loyalty.

Internet bank use based on trust for internet banking system and bank itself means satisfaction and loyalty for current trading bank (Kim \& Kim, 2002; Noh \& Lee, 2005; Han, 2004). We can suppose this satisfaction and attitude can affects continuity, so the following hypotheses 7 and 8 are established.

H7. Internet bank use affects continuity.

H8. Bank loyalty affects continuity.

As discussed, regarding internet banking, switching barrier include switching costs of psychological and emotional costs as well as economic costs. As factors of switching barriers, economic costs required changing (Dick \& Basu, 1994), barriers related to human relations (Berry \& Parasuraman, 1991), attractiveness of alternatives (Anderson \& Narus, 1990) are considered. The results of empirical test show that switching barriers have control effects on the trace from customer satisfaction to switching intention (Anderson et al., 1994; Jones et al., 2002; Gwinner, 1998).

On mobile banking research, switching barriers are turned out not to have control effects between customer satisfaction and switching intention (Kim \& Oh, 2007). However, the difference that the main benefits of mobile banking are movability, security, responsiveness while economic gains and convenience is the main benefits of internet banking should be considered (Kim \& Kim, 2002).

Taking the above discussion into account, we set up the following hypotheses 9 and 10. For switching barriers, switching costs, difficulties of adapting new environment, uncertainty of new bank is considered as sub-variables.

H9. Switching barriers have control effects while internet banking use affects continuity.

H9-1. Switching costs of switching barriers have control effects while internet banking use affects continuity.

H9-2. Difficulties of adapting new environment of switching barriers have control effects while internet banking use affects continuity.

H9-3. Uncertainty of new bank of switching barriers has control effects while internet banking use affects continuity.

H10. Switching barriers have control effects while bank loyalty affects continuity.

H9-1. Switching costs of switching barriers have control effects while bank loyalty affects continuity.

H9-2. Difficulties of adapting new environment of switching barriers have control effects while bank loyalty affects continuity.

H9-3. Uncertainty of new bank of switching barriers has control effects while bank loyalty affects continuity.

\subsection{Research Model}

The research model for this study can be drawn as follows.



Figure 1. Research model

\subsection{Composition and Data Collection of Questionnaire}

The questionnaire was composed of general questions, demographic characteristics, customer value, trust, internet banking use, bank loyalty, switching barrier, and continuity. The customer value was partially adapted to the purpose of this study, and the 22 items were composed of the values presented as ease of use, customer service, usefulness, customization, ease of use, interest (Kim \& Kim, 2002), economic usability, and customization (Kim \& Kim, 2004) 
The reliability of the system for internet banking and the trust of the bank were divided into questionnaires. Trust in the system was modified to fit this study based on the research of Kim and Kim (2002), Kim and Oh (2007), and Lee (2015). Based on the research by Kim et al. (2003), trust in the bank was modified and adjusted according to the study in consideration of the factors (Han, 2016 ; Park \& Ha, 2010) suggested by the trust related studies. It consists of 16 questions.

The questionnaire items related to the switching barriers and relationship continuity intention were selected and modified to fit the study by referring to the research of Kim and Oh (2007) and Kim and Han (2011). The questionnaires were distributed randomly from July to the end of September, 2018, and 300 copies were distributed and 287 copies were collected. The remaining 270 copies were excluded from the questionnaire. The analysis utilized SPSS 2.0 version.

\section{Empirical Analysis}

Empirical analysis was followed by demographic analysis and factor analysis. Regression analysis was conducted to verify whether each factor was affected, and analysis was conducted to verify whether switching barriers had a moderating effect.

\subsection{Demographic Characteristics}

The demographic composition of respondents is summarized in the following table.

Table 2. Demographic characteristics

\begin{tabular}{ll}
\hline Construct & Configuration \\
\hline Sex & Male: 116(43\%), Female: $154(57 \%)$ \\
Age & 20's: 55(20.4\%), 30's: 97(35.9\%), 40's: 92(34.1\%), 50's: 269.6\%) \\
Marital status & Married: 123(45.6\%), Unmarried: 147(54.4\%) \\
Education & J. College: 75, College: 164, Master attending: 6, Master and above: 25 \\
Income & Less than 100Man Won: 52, 100-200: 46, 200-300: 55, 300-400: 54, 400-500: 25, 500-600: 18, 600-700: 14, 700 \\
& and more: 6 \\
Occupation & Students: 24, Self-employed: 16, Blue-color: 17, Worker: 27, Specialist: 25, House-wife: 35, Etc: 26 \\
\hline
\end{tabular}

\subsection{Factor Analysis}

The results of the factor analysis are summarized in the following table.

Table 3. Summary of factor analysis

\begin{tabular}{lccc}
\hline Factor & Eigen value & Cronbach's alpha & Variance explained \\
\hline Customer value & & & 20.180 \\
$\quad$ Usefulness & 5.045 & 0.831 & 15.283 \\
Ease of use & 3.821 & 0.850 & 14.377 \\
Customization & 3.594 & 0.896 & 8.962 \\
Convenience & 2.240 & 0.867 & 38.794 \\
System trust & & & 33.027 \\
Task trust & 1.940 & 0.732 & 38.794 \\
Security trust & 1.651 & 0.783 & 18.983 \\
Bank trust & & & 14.059 \\
Promise & 3.369 & 0.851 & 83.866 \\
Opportunity & 2.278 & 0.653 & 55.926 \\
Employee & 1.687 & 0.759 & 31.720 \\
Internet Banking use & 1.677 & 0.807 & 17.597 \\
Bank loyalty & 2.796 & 0.800 & 12.598 \\
Switching barrier & & & 58.731 \\
$\quad$ Switching costs & 4.758 & 0.778 & \\
$\quad$ Difficulties of New environment & 2.640 & 0.896 & 0.759 \\
$\quad$ Uncertainty of new Bank & 1.890 & 0.735 & \\
Continuity & 1.762 & & \\
\hline
\end{tabular}


In the above table, reliability analysis shows that there is no problem in reliability because all of them are 0.7 or more except for opportunistic behavior. Factor analysis results for each independent variable are as described above. The following are the results of correlation analysis between independent variables.

Table 4. Summary of correlation analysis of independent variables

\begin{tabular}{|c|c|c|c|c|c|c|c|c|c|}
\hline \multicolumn{10}{|c|}{ Usefulness Ease of use Customization Convenience Task trust Security trust Promise Opportunity Employee } \\
\hline Usefulness & 1 & & & & & & & & \\
\hline Ease of use & .329 & 1 & & & & & & & \\
\hline Customization & .218 & .181 & 1 & & & & & & \\
\hline Convenience & .267 & .294 & .099 & 1 & & & & & \\
\hline Task trust & .303 & .377 & .200 & .438 & 1 & & & & \\
\hline Security trust & .073 & .055 & .363 & -.004 & .203 & 1 & & & \\
\hline Promise & .181 & .119 & .265 & .136 & .286 & .537 & 1 & & \\
\hline Opportunity & .185 & .211 & .068 & .171 & .220 & -.112 & -.158 & 1 & \\
\hline Employee & .208 & .192 & .192 & .187 & .323 & -.184 & .261 & .042 & 1 \\
\hline
\end{tabular}

\subsection{Regression Analysis}

As a result of the factor analysis, customer value converged with usefulness, excellence, customization and convenience, and system trust related to banking of internet banking is extracted as trust and safety trust. Trust in the bank itself consisted of commitment, opportunistic behavior, and employee confidence. The following are the results of analyzing the influence of factors extracted by factor analysis.

Table 5. Summary results of regression analysis

\begin{tabular}{|c|c|c|c|c|c|c|c|}
\hline Independent Variable & Dependent Variable & Std. Error & beta & t-value & significant & Adj. R2 & $\mathrm{F}$ \\
\hline Customer value & Internet Banking use & & & & & & \\
\hline - Usefulness & & .061 & .408 & 7.308 & .000 & .163 & 53.41 \\
\hline - Ease of use & & .056 & .387 & 6.873 & .000 & .147 & 47.23 \\
\hline -customization & & .047 & .188 & 3.141 & .000 & .032 & 9.866 \\
\hline - Convenience & & .050 & .477 & 8.894 & .000 & .225 & 79.10 \\
\hline System trust & Internet Banking use & & & & & & \\
\hline -Task trust & & .051 & .604 & 12.408 & .000 & .362 & 153.7 \\
\hline -Security trust & & .043 & .060 & .992 & .322 & .000 & .984 \\
\hline Bank trust & Internet Banking use & & & & & & \\
\hline -Promise & & .051 & .297 & 5.098 & .000 & .085 & 25.99 \\
\hline -Opportunity & & .050 & .228 & 3.840 & .000 & .049 & 14.75 \\
\hline -Employee & & .057 & .258 & 4.374 & .000 & .063 & 19.13 \\
\hline Customer value & Bank loyalty & & & & & & \\
\hline -Usefulness & & .071 & .252 & 4.272 & .000 & .060 & 18.25 \\
\hline -Ease of use & & .062 & .359 & 6.291 & .000 & .125 & 39.58 \\
\hline -Customizaiton & & .050 & .314 & 5.419 & .000 & .095 & 29.36 \\
\hline -Convenience & & .061 & .256 & 4.332 & .000 & .062 & 18.76 \\
\hline System trust & Bank loyalty & & & & & & \\
\hline -Task trust & & .064 & .434 & 7.882 & .000 & .185 & 62.12 \\
\hline -Security trust & & .046 & .283 & 4.828 & .000 & .077 & 23.31 \\
\hline Bank trust & Bank loyalty & & & & & & \\
\hline -Promise & & .061 & .304 & 5.230 & .000 & .089 & 27.35 \\
\hline -Opportunity & & .057 & .027 & .438 & .661 & -.003 & .192 \\
\hline -Employee & & .063 & .249 & 4.210 & .000 & .059 & 17.73 \\
\hline Internet Banking use & Bank loyalty & .062 & .398 & 7.105 & .000 & .155 & 50.48 \\
\hline Bank Loyalty & Internet Banking use & .398 & .051 & 7.105 & .000 & .155 & 50.48 \\
\hline Internet Banking use & Continuity & .065 & .332 & 5.769 & .000 & .107 & 33.28 \\
\hline Bank loyalty & Continuity & .052 & .550 & 11.068 & .000 & .311 & 122.5 \\
\hline
\end{tabular}

Among the customer values, usefulness, convenience, customization, and convenience all have a significant 
effect on the adoption of Internet banking. These results are consistent with the convenience results of Kim \& Kim (2002), and different results are obtained in the case of customization and usability. In the case of customization, it can be concluded that the result of the study by Noh and Lee (2005) suggests the result of verification with customer value. The effect of trust on the system on the adoption of Internet banking is related to the results of Kim and Kim (2002). Kim and Kim (2002) report that customer loyalty to Internet banking sites leads to loyalty to banks. The results of Kim et al. (2003) related to bank trust on the adoption of Internet banking set the sub-variables as compliance with commitments and abuse of opportunities in bank trust, and high income group and low income group had significant influence on opportunity abuse and commitment The results are presented. These results are generally similar to the results of this study. The results of this study are as follows. The results of system trust have a significant effect on customer loyalty, which is similar to the results of Noh and Lee (2005), Han (2004) and Lee (2015), and almost same to the results of those Gwinner et al. (1998), Garbarino \& Johnson (1999), and Reichheld (2000) who suggested that trust is more important than treatment.

On the other hand, the trust for the bank employees in this study has a significant effect on the internet banking use. The results of the analysis of the effect of internet banking - related customer value on loyalty to the bank showed that the usefulness, excellence, customization, and convenience are significant for bank loyalty. These results are consistent with the results of Kim and Kim (2002) and Lee (2015) that loyalty to Internet banking sites has a significant effect on bank loyalty. In the case of mobile banking, the results are similar to the results of internet banking.

The results of this analysis show that trust in the trust of Internet banking system has no significant effect on adoption of Internet banking. These results are interpreted as a result of expressing concerns about hacking or disclosure of external information. In addition, bank opportunistic behavior has a significant effect on intention to use internet banking, which is consistent with the results of Kim et al. (2003), but the loyalty to the bank itself is not significant. The results of this study are as follows. First, we examine the relationship between bank loyalty and bank loyalty. First, bank loyalty is positively related to bank loyalty. On the other hand, it can be interpreted that internet banking has an attitude to adopt even considering the fact that internet banking has a significant influence on adoption.

In addition, the adoption of Internet banking has a significant effect on the loyalty of the bank, and the loyalty of the bank also has a significant effect on the adoption of the Internet banking. In addition, the adoption of internet banking and bank loyalty has been shown to have a significant influence on the relationship persistence. This result is similar to the results of Noh and Lee (2005), and it is consistent with the results of mobile banking study that customer satisfaction has a negative effect on the conversion intention (Kim, 2007).

\subsection{Control Effect Analysis}

\subsubsection{Analysis Contents}

One of the main concerns of this study is the analysis of the role of conversion barriers in relation to the prevention of departure of existing customers and the verification of whether switching costs are controlled in the process of adoption of internet banking.

The results of this study are as follows. First, the effect of the adoption of the path - related Internet banking on the sustainability of the relationship and the bank loyalty and the relationship between the two. The control effect is determined by whether or not the explanatory power (R2) is significantly increased under the significance level.

\subsubsection{Analysis Results}

In the process of adopting Internet banking, the following table shows the analysis results on the effect of conversion cost, the difficulty of adapting to new environment, and the effect of changing bank uncertainty. First, it can be seen that the conversion cost does not have a modulating effect as shown in the following table.

Table 6. Summary of control effect analyses of switching costs on internet banking use and continuity process

\begin{tabular}{cccccccc}
\hline Model & Adj. R sq. & Std. Error & \multicolumn{5}{c}{ Variation of Statistics } \\
\hline & & & Variation of R sq. & Variation of F value & df1 & df2 & Significance Prob. of F \\
\hline 1 & .096 & 1.055 & .099 & 29.608 & 1 & 268 & .000 \\
2 & .093 & 1.057 & .000 & .000 & 1 & 267 & .999 \\
3 & .090 & 1.057 & .001 & .175 & 1 & 266 & .676 \\
\hline
\end{tabular}


Table 7. Summary of control effect analyses of difficulty of new environment on internet banking use and continuity process

\begin{tabular}{cccccccc}
\hline Model & Adj. R sq. & Std. Error & \multicolumn{5}{c}{ Variation of Statistics } \\
\hline & & & Variation of R sq. & Variation of F value & df1 & df2 & Significance Prob. of F \\
\hline 1 & .096 & 1.055 & .099 & 29.608 & 1 & 268 & .000 \\
2 & .093 & 1.057 & .000 & .033 & 1 & 267 & .856 \\
3 & .090 & 1.059 & .000 & .092 & 1 & 266 & .762 \\
\hline
\end{tabular}

It can be seen from the above table that the difficulty of adaptation to the new environment also has no control effect. The following is the uncertainty of the replacement bank.

Table 8. Summary of control effect analyses of uncertainty of new bank on internet banking use and continuity process

\begin{tabular}{cccccccc}
\hline Model & Adj. R sq. & Std. Error & \multicolumn{5}{c}{ Variation of Statistics } \\
\hline & & & Variation of R sq. & Variation of F value & df1 & df2 & Significance Prob. of F \\
\hline 1 & .096 & 1.055 & .099 & 29.608 & 1 & 268 & .000 \\
2 & .098 & 1.054 & .005 & 1.633 & 1 & 267 & .202 \\
3 & .115 & 1.045 & .019 & 5.906 & 1 & 266 & .016 \\
\hline
\end{tabular}

In the above table, the uncertainty of the replacement bank has a moderate effect. The uncertainty of the bank that switched to the new bank after adoption of the Internet banking is the result of influencing the change of the Internet bank.

The following is an analysis of whether switching costs have a moderating effect in the process of bank loyalty affecting the relationship continuity. First, the results of the analysis on whether or not the conversion cost is controlled are summarized in the following table.

Table 9. Summary of control effect analyses of switching costs on bank loyalty and continuity process

\begin{tabular}{cccccccc}
\hline Model & Adj. R sq. & Std. Error & \multicolumn{5}{c}{ Variation of Statistics } \\
\hline & & & Variation of R sq. & Variation of F value & df1 & df2 & Significance Prob. of F \\
\hline 1 & .097 & 1.055 & .000 & 29.865 & 1 & 268 & .000 \\
2 & .095 & 1.056 & .001 & .300 & 1 & 267 & .584 \\
3 & .094 & 1.057 & .003 & .875 & 1 & 266 & .350 \\
\hline
\end{tabular}

In the above table, it can be seen that the conversion cost does not have a moderating effect in the process of bank loyalty affecting the relationship persistence. The following is the analysis result of whether or not the adjustment difficulty of the new environment adaptation effect.

Table 10. Summary of control effect analyses of difficulties of new environment on bank loyalty and continuity process

\begin{tabular}{cccccccc}
\hline Model & Adj. R sq. & Std. Error & \multicolumn{5}{c}{ Variation of Statistics } \\
\hline & & & Variation of R sq. & Variation of F value & df1 & df 2 & Significance Prob. of F \\
\hline 1 & .097 & 1.055 & .100 & 29.865 & 1 & 268 & .000 \\
2 & .094 & 1.057 & .000 & .040 & 1 & 267 & .842 \\
3 & .099 & 1.054 & .009 & 2.562 & 1 & 266 & .111 \\
\hline
\end{tabular}

In the above table, it can be seen that the difficulty of adaptation to the new environment does not have a moderating effect in the process of bank loyalty affecting the relationship persistence. The following are the results of the analysis of the effect of the regulatory uncertainty on the replacement bank.

Table 11. Summary of control effect analyses of uncertainty of new bank on bank loyalty and continuity process

\begin{tabular}{cccccccc}
\hline Model & Adj. R sq. & Std. Error & \multicolumn{5}{c}{ Variation of Statistics } \\
\hline & & & Variation of R sq. & Variation of F value & df1 & df2 & Significance Prob. of F \\
\hline 1 & .097 & 1.055 & .100 & 29.865 & 1 & 268 & .000 \\
2 & .094 & 1.056 & .001 & .288 & 1 & 267 & .592 \\
3 & .146 & 1.026 & .058 & 9.093 & 1 & 266 & .000 \\
\hline
\end{tabular}


In the table above, it can be seen that the bank loyalty has a moderating effect on the replacement bank's uncertainty in the process of affecting the relationship persistence.

\subsection{Sintering}

In summary, the results of the above regulatory effect analysis show that uncertainty about the replacement bank has a moderating effect in the process of the influence of the adoption of internet banking on the sustainability of the relationship and the influence of the bank loyalty on the sustainability of the relationship. These results suggest that there are some unreliable factors such as opportunistic behaviors that customers have about banks. Therefore, even if customers change from an existing bank to another bank, they cannot benefit from special advantages or benefits, and that there is a possibility that there will be a lot of trouble. The results of this study are different from those of Kim (2007), who suggested that the results of analyzing the adjustment effect of conversion barriers in the process of customer satisfaction affecting the conversion intention in mobile banking study Results are shown.

\section{Conclusion}

In this study, we examined the factors affecting the adoption of Internet banking and the relationship. It is one of the ways to maintain the competitiveness of banks and increase their profits in the face of the emergence of Internet professional banks and the emergence of new and various banking channels. This is because it is judged that the tendency analysis is very urgent.

To summarize the results, usefulness, excellence, customization, and convenience of customer value have significant effects on adoption of internet banking. These results are somewhat different from those of the earlier period when Internet banking was introduced. As the internet banking becomes more common, the value that customers perceive has become more diverse, and the result of reflecting the aspect of choosing Internet banking according to the way that each customer wants.

Trust in the system is divided into trust in the system and trust in the bank itself. Trust in the system has a significant effect on adoption of Internet banking, but trust in the trust has a significant effect Results are showing. This seems to be a reflection of the customer's perceived lack of confidence in the safety of the Internet system. The results of this study are as follows. First, the effect of bank commitment on trust in the bank has a significant effect on adoption of internet banking and loyalty to banks. However, opportunistic behavior has a significant effect on internet banking, and the confidence in the bank is partial.

The results of the analysis of the effect of internet banking - related customer value on loyalty to the bank showed that the usefulness, excellence, customization, and convenience are significant for bank loyalty. In addition, the adoption of Internet banking has a significant effect on the loyalty of the bank, and the loyalty of the bank also has a significant effect on the adoption of Internet banking. In addition, adoption of Internet banking and bank loyalty has a significant influence on the relationship persistence.

In summary, the results of the regression analysis show that uncertainty about the replacement bank has a moderating effect in the process of the influence of the adoption of internet banking on the sustainability of the relationship and the effect of the bank loyalty on the continuation of the relationship. This result is interpreted as a result of the recognition that it is difficult for a customer to have reliable trust or belief in a newly selected bank even if the bank is replaced with a bank to perform the Internet banking business. This result can be said to be consistent with the result that opportunistic behavior has no significant effect on loyalty to the bank among the sub - variables of trust to the bank.

New banking practices, such as the launch of an Internet bank and the widespread availability of non-face-to-face loans, are likely to cause major industry changes. In order to enhance competitiveness in such an environment, we should focus on maintaining existing customers and securing new customers. In order to do this, it is necessary to understand what the value is perceived by customers and thoroughly analyze the barriers to conversion. It is necessary to remind customers that they are attracting customers by identifying and providing the value they recognize, and that the barriers to conversion can be a cost-perceived barrier to customers, as indicated by Porter (1980). In other words, understanding the conversion barrier can reduce the intention of the customer to convert, and thus there is not too much room to retain the acquired customer and to utilize it to attract third-party customers.

In this study, we examined the effect of customer value, trust, and conversion barrier on internet banking adoption. This study analyzed the relationship between customer value and the adoption of Internet banking, the distinction between trust in trust systems and trust in banks, and the effect of the adjustment of switching barriers. It is anticipated that it will be possible to obtain information on the propensity of customers to improve the 
profitability of banks.

In this study, we tried to analyze the effect of customer value on the adoption of Internet banking, and it could be a more systematic study if the researcher includes the factors that influence customer value. In addition, a comparative study with mobile banking will also help to make a more systematic interpretation of the research results.

\section{References}

Abdallah, A., Yogesh, K. D., Nripendra, P. R., \& Read, A. (2018). Examining factors influencing Jordanian customers' intentions and adoption of internet banking: Extending UTAUT2 with risk. Journal of Retailing and Consumer Services, 40, 125-138. https://doi.org/10.1016/j.jretconser.2017.08.026

Allen, N. J., \& Meyer, J. P. (1991). The measurement and antecedents of affective, continuance and normative commitment to the organization. Journal of Occupational Psychology, 63, 1-18. https://doi.org/10.1111/j.2044-8325.1990.tb00506.x

Anderson, E. W. (1994). Cross-category variation in customer satisfaction and retention. Marketing Letters, 5(1), 19-30. https://doi.org/10.1007/BF00993955

Anderson, E. W., \& Sullivan, M. W. (1993). The antecedents and consequences of customer satisfaction for firms. Marketing Science, 12(2), 125-143. https://doi.org/10.1287/mksc.12.2.125

Anderson, J. C., \& Narus, J. A. (1990). A model of distributor firm and manufacturer firm working partnerships. the Journal of Marketing, 42-58. https://doi.org/10.2307/1252172

Bart, Y., Shankar, V., Sultan, F., \& Urban, G. L. (2005). Are the drivers and role of online trust the same for all web sites and consumers? A large scale exploratory empirical study. Journal of Marketing, 69(4), 133-52. https://doi.org/10.1509/jmkg.2005.69.4.133

Becker, H. S. (1960). Notes on the Concept of Commitment. American Journal of Sociology, 66, 32-42. https://doi.org/10.1086/222820

Bendapudi, N., \& Berry, L. L. (1997). Customers' motivations for maintaining relationships with service providers. Journal of Retailing, 73(1), 15-37. https://doi.org/10.1016/S0022-4359(97)90013-0

Berger, P. D., \& Nasr, N. I. (1998). Customer lifetime value: Marketing models and applications. Journal of Interactive Marketing, 17-30. https://doi.org/10.1002/(SICI)1520-6653(199824)12:1<17::AID-DIR3>3.0.CO;2-K

Berraies, S., Ben Yahia, K., \& Hannachi, M. (2017). Identifying the effects of perceived values of mobile banking applications on customers: Comparative study between baby boomers, generation $\mathrm{X}$ and generation Y. International. Journal of Bank Marketing, 35(6), 1018-1038. https://doi.org/10.1108/IJBM-09-2016-0137

Berry, L. L., \& Parasuraman, A. (1991). Marketing Services-Competing Through Quality. New York: Free Press.

Boulding, W., Kalra, A., Staelin, R., \& Zeithaml, V. A. (1993). A dynamic process model of sevice quality: From expectations to behavioral intentions. Journal of Marketing Research, 30(1), 7-27. https://doi.org/10.2307/3172510

Cho, K. H., \& Park, B. G. (1999). An Empirical Study of the Effects of the Switching Barrier and Customer Satisfaction on Store Loyalty. Journal of Management, 28(1), 127-149.

Coleman, J. S. (1990). Foundations of Social Theory. Cambridge, MA: Belknap Press.

Curral, S. C., \& Judge, T. H. (1995). Measuring trust between organizational boundary role persons. Organizational Behavior and Human Decision Process, 64(2), 151-70. https://doi.org/10.1006/obhd.1995.1097

Day, G. S. (1969). A Two-Dimensional Concept of Brand Loyalty. Journal of Advertising Research, 9(September), 29-35.

Dick, A. S., \& Basu, K. (1994). Customer loyalty: Toward an integrated conceptual framework. Journal of the Academy of Marketing Science, 22(2), 99-113. https://doi.org/10.1177/0092070394222001

Dwyer, F. R., Schurr, P. H., \& Oh, S. (1987). Developing buyer-seller relationships. The Journal of Marketing, 11-27. https://doi.org/10.2307/1251126

Ganesan, S. (1994). Determinants of long-term orientation in buyer-seller relationships. The Journal of Marketing, 1-19. https://doi.org/10.2307/1252265 
Gerpott, T. J., Rams, W., \& Schindler, A. (2001). Customer retention, loyalty, and satisfaction in the German mobile cellular telecommunications market. Telecommunications Policy, 25(4), 249-269. https://doi.org/10.1016/S0308-5961(00)00097-5

Geyskens, I., Steenkamp, J. B. E., Scheer, L. K., \& Kumar, N. (1996). The effects of trust and interdependence on relationship commitment: A trans-Atlantic study. International Journal of Research in Marketing, 13(4), 303-317. https://doi.org/10.1016/S0167-8116(96)00006-7

Goff, B. G., Boles, J. S., Bellenger, D. N., \& Stojack, C. (1997). The influence of salesperson selling behaviors on customer satisfaction with products. Journal of Retailing, 73, 171-84. https://doi.org/10.1016/S0022-4359(97)90002-6

Gremler, D. D., Bitner, M. J., \& Evans, K. R. (1995). The internal service encounter. Logistics Information Management, 8(4), 28-34.

Gupta, S., \& Lehmann, D. R. (2003). Customer as assets. Journal of Interactive Marketing, 17(1), 9-24. https://doi.org/10.1002/dir.10045

Han, S. I. (2004). The Determinants of User Adoption of Internet Banking. Journal of Korea Industrial Economics, 17(6), 2405-2428.

Jain, D., \& Singh, S. (2002). Customer lifetime value research in marketing: A review and future directions. Journal of Interactive Marketing, 16, 34-46. https://doi.org/10.1002/dir.10032

Jones, M. A., Mothersbaugh, D. L., \& Beatty, S. E. (2002). Why customers stay: Measuring the underlying dimensions of services switching costs and managing their differential strategic outcomes. Journal of Business Research, 55(6), 441-450. https://doi.org/10.1016/S0148-2963(00)00168-5

Kalwani, M. U., \& Narayandas, N. (1995). Long-term manufacturer-supplier relationships: Do they pay off for supplier firms? The Journal of Marketing, 1-16. https://doi.org/10.2307/1252010

Keaveney, S. M. (1995). Customer switching behavior in service industries: An exploratory study. The Journal of Marketing, 71-82. https://doi.org/10.2307/1252074

Kim, H. J., \& Han, J. S. (2012). The Study on the Relationships among Airline Image, Perceived Value, Customer Satisfaction and Customer Loyalty. Korean Journal of Hospitality \& Tourism, 21(4), 53-68.

Kim, H. W., \& Park, C. G. (2002). The Impact of Internet Banking on the Performance of the Korean Banking Industry: An Empirical Analysis. KDI Policy Research, 25(2), 91-135.

Kim, J. H., \& Lee, T. H. (2015). A Study on the Impact of Airline Service Quality on Customer Value, Customer Satisfaction, and Customer Voluntary Behavioral Intention : Focusing on Airline Cultural Services. Journal of Culture Industry, 15(4), 89-99.

Kim, J. S., \& Kim, Y. G. (2002). The Effect of Customer's Perceived Value of Internet Banking on customer Loyalty. Asia Pacific Journal of Information Systems, 12(4), 215-235.

Kim, K. G, Lee, J. W., \& Kim, H. S. (2003). Impact of Trust and Risk on Internet Banking Adoption. Management Research, 32(6), 1771-1797.

Kim, Y. T., \& Oh, J. C. (2007). An Empirical Study on Effect of Mobile Banking Service Quality on Customer Loyalty and Switching Intention. Korea Journal of Business Administration, 20(6), 2855-2877.

King, W. R., \& Epstein, B. J. (1983). Assessing Information System Value: An Experimental Study. Decision Science, 14(1), 34-45. https://doi.org/10.1111/j.1540-5915.1983.tb00167.x

LaBarbera, P. A, \& David, M. (1983). A Longitudinal Assessment of Consumer Satisfaction/Dissatisfaction: The Dynamic Aspect of the Cognitive Process. Journal of Marketing Research, 20(November), 393-404. https://doi.org/10.2307/3151443

Lee, M. S. (2015). Internet banking website service quality confidence, perception of security risks and their impact on e-loyalty. Consumer Culture Study, 18(1), 113-134.

Mathwick, C., Malhotra, N., \& Rigdon, E. (2001). Experiential value: conceptualization, measurement and application in the catalog and Internet shopping environment. Journal of Retailing, 77(1), 39-56. https://doi.org/10.1016/S0022-4359(00)00045-2

Mayer, R. C., Davis, J. H., \& Schoorman, F. D. (1995). An integrative model of organizational trust. Academy of Management Review, 20(3), 709-734. https://doi.org/10.5465/amr.1995.9508080335 
Moorman, C., Deshpande, R., \& Zaltman, G. (1993). Factors affecting trust in market research relationships. The Journal of Marketing, 81-101. https://doi.org/10.2307/1252059

Newman, J. W., \& Werbel, R. A. (1973). Multivariate analysis of brand loyalty for major household appliances. Journal of Marketing Research, 404-409. https://doi.org/10.2307/3149388

Noh, Y., \& Kim, Y. G. (2005). A Study on the Effects of Internet Banking Services Quality on Customer Value and Customer Satisfaction. The e-Business Studies, 6(3), 221-247.

Nooteboom, B., Berger, H., \& Noorderhaven, N. G. (1997). Effects of trust and governance on relational risk. Academy of Management Journal, 40(2), 308-338.

Oh, H. C. (1995). An empirical study of the relationship between restaurant image and customer loyalty (Doctoral dissertation, Virginia Tech).

Oliver, R. L. (1997). Satisfaction: A Behavioral Perspective on the Customer. New York NY: The McGraw-Hill Inc.

Park, T. Y., \& Ha, G. S. (2010). Research on the impact of trust in the savings bank on trading intent. Conference of Korea integrated academic publication Proceedings, 1-25.

Porter, M. E. (1980). Competitive strategy. New York: Free Press.

Porter, M. E. (1990). The Competitive Advantage of Nations. New York: Free Press. https://doi.org/10.1007/978-1-349-11336-1

Rahi, S., Ghani, M. A., \& Alnaser, F. M. (2017). The influence of e-customer services and perceived value on brand loyalty of banks and internet banking adoption: A structural equation model (SEM). The Journal of Internet Banking and Commerce, 22(1), 1-18.

Reichheld, F. F., \& Sasser, J. W. (1990). Zero defections: Quality comes to services. Harvard Business Review, 68(5), 105-111.

Rodriges, S. J., Callarisa, L. L. J., Rodriguez, R. M., \& Moliner, M. A. (2006). Perceived value of the purchase of a tourism product. Tourism Management, 27(4), 121-651.

Sambandam, R., \& Lord, K. R. (1995). Switching behavior in automobile markets: A consideration-sets model. Journal of the Academy of Marketing Science, 23(1), 57-65. https://doi.org/10.1007/BF02894612

Shin, D. S. (2011). Effects on LOHAS Image of Family Restaurant, Customer Value, Customer Satisfaction and Intention of Relation. Service Management Journal, 12(1), 189-216.

Smith, A. K., \& Bolton, R. N. (1998). An experimental investigation of customer reactions to service failure and recovery encounters: Paradox or peril?. Journal of Service Research, 1(1), 65-81. https://doi.org/10.1177/109467059800100106

Sweeney, J. C., \& Soutar, G. N. (2001). Customer Perceived Value: the Development of a Multiple Item Scale. Journal of Retailing, 77(2), 203-220. https://doi.org/10.1016/S0022-4359(01)00041-0

Tuškej, U., Golob, U., \& Podnar, K. (2013). The role of consumer-brand identification in building brand relationships. Journal of Business Research, 66(1), 53-59. https://doi.org/10.1016/j.jbusres.2011.07.022

Yun, H. S., Mao, J., \& Bae, S. W. (2013). The Relationship between Customer Satisfaction and Relationship Continuity Intention and the Moderating Role of Regulatory Focus on its Relationship: A Comparative Study between Korea and China. Journal of Marketing Management Research, 21(1), 49-67.

Zeithaml, V. A. (2000). Service quality, profitability, and the economic worth of customers: What we know and what we need to learn. Journal of the Academy of Marketing Science, 28(1), 67-85. https://doi.org/10.1177/0092070300281007

Zeithaml, V. A., Berry, L. L., \& Parasuraman, A. (1996). The behavioral consequences of service quality. The Journal of Marketing, 31-46. https://doi.org/10.2307/1251929

\section{Copyrights}

Copyright for this article is retained by the author(s), with first publication rights granted to the journal.

This is an open-access article distributed under the terms and conditions of the Creative Commons Attribution license (http://creativecommons.org/licenses/by/4.0/). 